Article

\title{
City and Industry: How to Cross Borders? Learning From Innovative Company Site Transformations
}

\author{
Britta Hüttenhain * and Anna Ilonka Kübler \\ Institute of Urban Planning and Design, University of Stuttgart, Germany; \\ E-Mails: britta.huettenhain@si.uni-stuttgart.de (B.H.), annakuebler89@googlemail.com (A.I.K.) \\ * Corresponding author
}

Submitted: 28 February 2021 | Accepted: 21 June 2021 | Published: 23 September 2021

\begin{abstract}
While working and living coexisted in the historical city, the functions are separated in the Modernist city. Recently, the idea of connected urban districts with short distances and attractive work spaces have received renewed attention from companies and planners alike, as soft site factors, tacit knowledge, and local production are gaining importance. In this article we focus on the development of multi-national company sites and the economic and spatial conditions that encourage them to transform existing sites, improve placemaking, and cross borders. We also have a look at their interactive influence on the neighbourhood. We talked to the real estate managers of BASF, BMW, Bosch, Siemens, and Trumpf about site development strategies and approaches for connecting and mixing functions, and therefore crossing borders and, where it is necessary, separating. The professional discourse on "productive cities" and "urban manufacturing" is concerned with reintegrating production into the city. Reurbanisation is especially instrumental in overcoming a major guiding principle or dogma of the Modernist city: the separation of functions. Nevertheless, reurbanisation results in price rises and increases the competition for land. Therefore, planning has to pay attention to industrial areas, as well as housing or the inner-city. An important thesis of the article is that multi-national companies are pioneers in transforming their priority sites to suit future development. For cities, it is an upcoming communal task to ensure that all existing industrial areas develop into "just, green and productive cities," as pointed out in the New Leipzig Charter. To a certain extent, it is possible to adapt the urban planning and design strategies of multi-national companies for existing industrial areas. This is especially true regarding the question of how borders and transition zones between industrial areas of companies and the surrounding neighbourhood can be designed to be spatially and functionally sustainable or how they can be transformed to suit future urban needs. However, urban planning has to balance many concerns and therefore the article concludes with a synopsis of the importance of strategic planning for transforming existing industrial areas.
\end{abstract}

\section{Keywords}

company sites; economic development; global players; industrial areas; just city; productive city; strategic planning; transition zones; urban planning and design; urban resilience

\section{Issue}

This article is part of the issue "Future Commercial and Industrial Areas" edited by Angela Million (TU Berlin, Germany) and Felix Bentlin (TU Berlin, Germany).

(C) 2021 by the authors; licensee Cogitatio (Lisbon, Portugal). This article is licensed under a Creative Commons Attribution 4.0 International License (CC BY).

\section{Introduction}

Cities are subject to constant change, depending on geographical conditions, economic development, and political constellations. Economic and urban development have a correlating influence on each other and become visible in the built environment and the urban morphology. After years of separating functions and developing new industrial areas on greenfield sites it is obvious that ecological aspects and brownfield sites play an important role for future development. Companies and cities are facing a comprehensive transformation and digitalisation 
process - strengthened by the Covid-19 pandemic - that needs to be designed to keep European cities and companies competitive. The success of the transformation will depend on the global players, as well as the diverse small and medium-sized manufacturing industries, the land owners, and urban politics.

In the New Leipzig Charter of 2020, the EU ministers for Urban Matters emphasise the pursuit of the common good using the transformative power of cities. They confirm three dimensions that contribute to developing resilient cities taking into account ecology, economy and social issues, and secure competitiveness, as well as ensuring prosperity: the just city, the green city, and the productive city (EU, 2020). In the global context, the UN speaks of sustainable development goals and in the financial sector of environment, social, and governance ratings. All these publications reinforce the necessity to transform our cities and point out the challenge to balance different interests to ensure greater justice.

Research projects show the need for a new discourse on "productive cities" if European cities are to stay competitive and ensure prosperity. Therefore, urban manufacturing and local material flows need more attention as important urban functions (e.g., Bathen et al., 2019; Croxford et al., 2020; Hosoya \& Schäfer, 2020; Läpple, 2019). Other studies focus more on existing industrial areas as "blind spots" of our discipline that need new spotlighting and strategic urban planning to raise the hidden potentials in these city areas and the interactive influence for the future (e.g., Bundesinstitut für Bau-, Stadt- und Raumforschung, 2020; Eckmann et al., 2020; Förster et al., 2017; Roost et al., 2021; Schmitt et al., 2019). However, the studies pay little attention to multi-national companies (e.g., Volkswagen in Wolfsburg; Bosch, Daimler, and Porsche in Stuttgart; BMW in Munich; BASF in Ludwigshafen; Siemens in Erlangen, Berlin, and Munich) or to developments that take place in these settings. Although these companies can be seen as pioneers for transforming existing sites, new working environments, or material cycles (depending on the site), at the same time, they generate markets that have an impact on the district and far beyond local value creation.

In this article, we explore the activities of such global players in terms of the necessity and forms of interconnecting industrial areas with surrounding neighbourhoods, asking what we could learn from them in transforming industrial sites to suit the needs of the economy, both today and in the future. We focus on the scale of urban design. This might sound trivial, but implementing integrated spatial developments is far from being common practice, and the idea of qualified mixed-use industrial areas is far from new. We can find best-practiceprojects since the 1990s, especially the transformation of large-scale areas (e.g., Basel, Dreispitz, Werksviertel Munich, Zurich-West).

In addition to previous research in the Region of Stuttgart and best-practice studies, we talked to the real estate managers of BASF, Bosch, BMW, Siemens, and Trumpf. The aim was firstly to structure and reflect on their approaches of connectivity, i.e., type, degree, and strategy (see Section 3), and secondly to generalise what urban planning and design might learn to promote sustainable and productive business districts in a "just city" (see Section 4).

\section{Cities and Industry: Historical View}

The relationship between cities and industry is in constant flux and there are several interdependencies that form and transform city-districts. Before looking at what is going on today, we will take a brief look at guiding principles, opportunities, and pressures that have created new forms of industrial areas in the last century to show continuities and discontinuities.

\subsection{Unity of Production, Distribution, and Consumption Under One Roof}

In the medieval city, work was an integral part of urban life and different types of work were reasons to found cities. Work founded and shaped the city (Böhme, 2004, p. 180). Living and working closely linked and form a unity of production, distribution, and consumption under one roof. Businesses were small in scale, familyoperated, and showed diverse forms of economic selforganisation. Besides a fine-grained mix of uses, some specialised neighbourhoods emerged (Pesch, 2004, p. 9). Living inside the city walls was associated with the hope of a better life and future which is associated with the phrase "Stadtluft macht frei" (city air makes you free).

In the following years, cities grew steadily as the importance of international trade increased, and a new economic order of concentration of capital and labour through publishers, manufactories, and factories took hold. Division of labour and specialisation were strengthened by new technical tools and machines, and the textile, mining, and steel industries became engines of economic development (Pesch, 2004, p. 11).

\subsection{Inner-City Mixed Use and Peripheral Areas}

From the 16th to the 19th century, the population grew continuously (e.g., Manchester: from 75,000 inhabitants in 1800 to 700,000 in 1900; Berlin: 172,000 inhabitants in 1800 to 1.9 million in 1900). The demand for goods increased significantly during that period. Industry responded with enhanced productivity levels through mechanisation and rationalisation that allowed a more advanced division of labour and provided a number of benefits in terms of cost, production volumes, and efficiencies, which remain relevant until today (Croxford et al., 2020, p. 36).

During industrialisation in the 19th century, the dynamic urban development showed various characteristics. On the one hand, the invention of the railway as 
a means of transport enabled the expansion of cities, and peripheral greenfield sites were developed. On the other hand, urban locations densified, and the urban structure transformed. Instead of small-scale parcelled houses with vertical stacking of functions in one house, residential and commercial buildings within the urban block structure (keyword: backyard industry, challenging mix-use) were built. Despite conflicts, the mix of functions was necessary because the transport system was still underdeveloped, and short distances between working and living areas were evident. At the beginning of the industrial age, commercial sites usually showed highquality, monumental, multi-storey buildings, which still characterise many cityscapes today.

\subsection{Separation of Functions}

The increasing importance of the railway as a means of passenger transport and the availability of electricity, oil, and gas at every location gradually made it possible to separate housing and workplaces and to resolve the unacceptable living and working conditions in inner-city locations. The impulse to move outside the city became embedded in the European culture with the ideas of the "garden city" of Ebenezer Howard (in 1898) and the "Cité Industrielle" of Tony Garnier (about 1904). These were followed by the Athens Charter of CIAM (in 1933) with its dogma of separation of functions-living, working, leisure-which were connected by railway and automobile infrastructures. Manufacturing industries no longer fitted into the Modernist vision of city centres. Separation and Fordism became the guiding principles of urban planning in the 20th century (Häussermann et al., 2008, pp. 135-181), and segregation was the major collateral damage.

The idea of separation took full advantage of the central requirements of companies (e.g., increasing demand for space due to production on one level; centralisation of administration; special facilities for logistics; increasing independence of specific location; cost efficiency per location), but also facilitated the administrative handling of urban development.

Technological developments in the energy, transport, and especially telecommunications sectors led to a virtual shortening of distances, despite greater real distances. Widely spread separated urban landscapes emerged, divided into residential, office, shopping, and recreational centres-later described as "the in-between city" ("Zwischenstadt"; Sieverts, 1997). The negative consequences of this development included unattractive, monotonous urban structures that lacked atmosphere, diversity, and quality of experience in the neighbourhood, as well as expansive landscape consumption, high infrastructure costs, and noise and emission pollution from the resulting traffic.

The "economic miracle" in Germany during the 1950 s and 1960 s, with constantly growing prosperity and labour unions that steadily reduced working hours and achieved many amenities for employees, made the spatial disadvantages fade into the background.

From the 1970s onwards, the professional discourse publicised a stronger connection between uses and the reduction of suburbanisation for several reasons. In practice, however, only minor effects could be reached in the 20th century, although technological progress and environmental restrictions resulted in reduced distances (Pesch, 2004, p. 17).

\subsection{Urban Focus of the Knowledge Society}

The influence of the information and communication industry, the global division of labour-made possible by increasing automation and digitalisation-and the global limitedness of resources is fundamentally changing the world of work and urban development. A coexistence of centralisation and decentralisation can be observed. While standardised mass production is being relocated to cheaper locations in suburbia or to other parts of the world in order to lower production costs, various other conditions favour the reurbanisation of industry in the 21st century: human capital; tacit knowledge; war of talents; cluster strategies; cooperation with third-party companies and contractors; knowledge transfer to university research institutes; global networking. These are keywords that are addressed in this context (see, e.g., Roost et al., 2021, pp. 15-25). Since the turn of the millennium, we have observed that multi-national companies have invested a lot of time and effort to transform priority sites (often headquarters sites in metropolitan areas) to connect research and prototype development, as well as some parts of consumer-oriented requirements, in order to be viable.

In the EU's 2013 report on re-industrialisation, manufacturing industries are discussed as important drivers for the future (Stadtentwicklung Wien, 2017, p. 23) and, more and more, urban researchers point out the significance of developing "productive cities." One of the pioneers is Dieter Läpple (2020), who has announced that we face a fundamental and overdue structural transformation, prompted by the Covid-19 pandemic. The crisis offers the unique opportunity to transform the economy and he mentions resilience, supply security, and sustainability as paramount guiding principles, opening up new perspectives for the development of a new production logic. The conclusion for urban policymakers is that it is up to them to provide affordable land and intelligent governance structures for shaping productive cities (Läpple, 2020, p. 23).

\section{Connecting Company Sites: Observations of Field Study}

Multi-national companies often have an important impact on the urban context and the financial performance of municipalities, either directly through real estate developments, the influx of employees/ 
inhabitants, scaling effects on cooperating companies or indirectly through taxes and duties. The spheres of influence vary greatly in size and type. But, headquarters of large multi-national companies often have 10,000 to 40,000 employees, and thus generate decisive markets and influence surrounding areas.

We did a field study exploring the site development of several companies through literature studies and, where possible, on site. Besides this, we talked to the (former) real estate managers of BASF in Ludwigshafen, BMW in Munich, Bosch in Stuttgart, Siemens in Erlangen and Berlin, and Trumpf in Ditzingen. One finding of the interviews is that big players have the power to plan future developments strategically, have resources to deal with different future scenarios ahead of time, and have the capital to implement transformation. Consequently, a closer look at the large companies may give a good view of the current situation, especially how to motivate connectivity and design transition zones.

In this section, we describe and reflect on the types of connectivity between cities and industry that we discovered in the field study. There are already a lot of sites relevant for developing "just, green and productive cities" (EU, 2020, pp. 3-5). Our study, however, focuses on priority sites of companies and the urban design scale. We get back to this aspect in Section 4.

\subsection{Spatial and Structural Connection}

Structural change in the employment sector and in lifestyle offer starting points to rethink the interaction between company locations and their surroundings. In the last few years, in addition to high-quality, industrial architecture, or new industrial space concepts, the urban dimension continues to gain importance for companies themselves and in competitions awarded (Sgobba, 2012, p. 197). Recently, this fact has been emphasised by different professional activities. For instance, the German Industrial Building Award added the category
"Städtebauliche Anlagen" (Urban Context) to its list of awards; the EUROPAN Young Architects' Award dealt with the theme twice; and the International Building Exhibition, IBA'27 Stuttgart Region has included it into its themes and projects list. One theme of the IBA' 27 is the "productive city" and there are competitions going on for several different sites. One new area of development for industry, living, and leisure is a competition in Winnenden (IBA'27-Projekte), asking the participants to show ideas for connecting the so-far separated functions. The innovative next step will be the real estate implementation with different stakeholders.

Looking at the global players, three types of spatial and structural connection can be found (Figure 1).

\subsubsection{Connecting Through Architecture}

The representation of companies through architecture played an important role in industrial architecture at the beginning of the 20th century, as the prominent example of the AEG Turbine Hall (architect: Peter Behrens) in Berlin shows (Vonseelen, 2012, p. 155). High-quality architecture was and is used to represent the company and create a positive image, especially at visible locations or locations close to the customer. Similarly, in the discourses on urban production, a high value is attached to the façade and its design. It should not only serve to represent the company, but also react to the cityscape and the surrounding neighbourhood (Möllers et al., 2020, p. 22). Due to the intensive contact with external companies and trade visitors, as well as the increased quality expectations of employees, the design of research and development buildings in particular (Sgobba, 2012, p. 211) but also centrally located production buildings (e.g., Wittenstein, Fellbach) became more important. Architecture and high-quality construction often designed by renowned architects play a prominent role for the whole company site (e.g., Trumpf, Ditzingen). Some companies use a unique language of form and

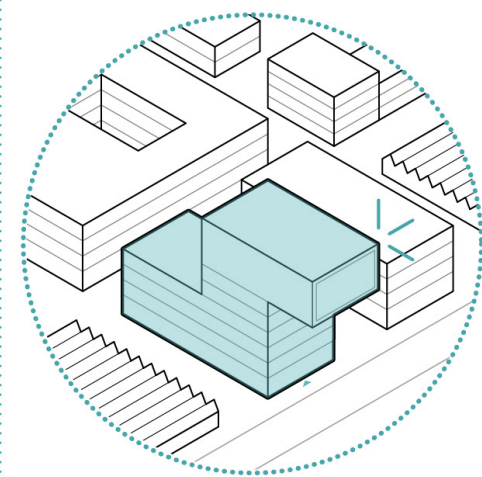

Architecture: buildings e.g., museums as landmarks that effect the image of the company/city

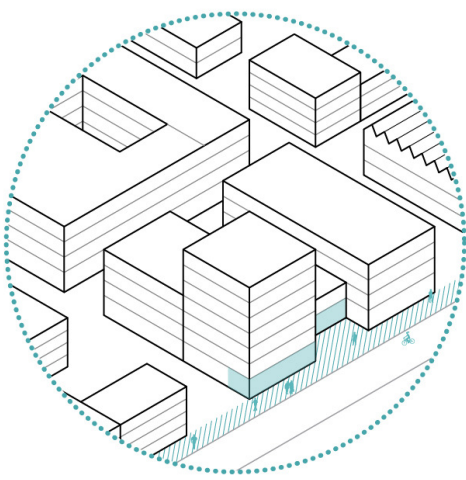

Urban Fabric: firms are visible through ground floor activities e.g., showrooms revitalise the street

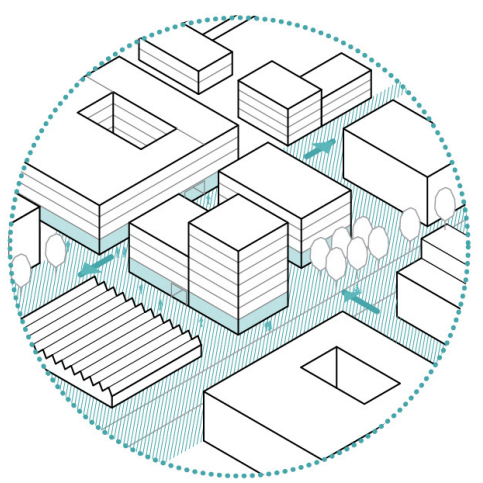

Interaction: the business district is accessible and some ground floor uses are public e.g., coffee shop

Figure 1. Types of spatial and structural connection (marked in green; see descriptions in Subsections 3.1.1-3.1.3). 
colour in the sense of corporate architecture and brand architecture (Sgobba, 2012, p. 175). These strategies are used as a communication offer (Daldrop, 2004, p. 61) for the environment, branding, strengthening recognition, and identification. Especially in the automotive industry, corporate architecture plays a major role, as shown by Fiat's former research and development building in Lingotto (in 1923) or BMW's four-cylinder administration building in Munich (in 1973). In some cases, high-quality buildings not only represent the company, but also contribute to the formation of identity with the city. In this way, an interrelationship between society and the company is very carefully established.

\subsubsection{Connecting Through Urban Fabric}

A new reputation for urban and open space qualities initially develops within closed factory sites. Meeting places become increasingly important as spaces for breaks and dialogue (e.g., Campus Novartis, Basel), especially at research and development locations. In some firms, the company site is zoned into different grades of publicness: more protection-intensive areas (prototypes/innovation in-house), public-friendly zones (exchange zones with external colleagues), and public-intensive zones (visitors). This can create attractive places for employees as well as representing the company when there are visitors from other companies (e.g., FIZ, BMW-Munich).

In addition to the internal zoning, companies are currently reassessing the connectivity to the surroundings and the integration into the urban fabric. Whereas some years ago a perimeter fence represented the boundary to the surroundings and a disruption in the urban fabric, these transition zones become deliberate "points of contact with the public" (Sgobba, 2012, p. 171). Here, the dialogue (adaptation vs. accentuation) with the spatial context forms the basis for structural contact points, such as the BMW administration building in Munich or the Daimler and Porsche museums in Stuttgart. Depending on the size and context of the site, these contact points can also be groundfloor public areas (e.g., showrooms) or attractive open spaces. In addition to the contact points, a spacious entrance to the street serves to make the adjacent public space more attractive and enhances the company's brand position.

\subsubsection{Connecting Through Interaction}

Another component of connectivity is to make the area accessible and to continue pathways or biking lanes that previously ended at the factory fence. This allows a higher permeability to the neighbourhood and is a further step to shorten distances. The area gets part of the city, instead of being a separate island in the urban structure and blind spot on the mental city map. The study shows two types of interaction. On the one hand, there is large-scale transformation that requires a high level of investment and is of high interest for companies and cities alike. Examples are the Siemens site development plans in Berlin and Erlangen, as well as the finished corporate headquarter in Munich. Another example is the Zalando headquarters in Berlin. Raised and open ground floor zones make it possible to accommodate other uses (e.g., co-working spaces, local suppliers) and improve transition zones. On the other hand, connectivity gets more important in "normal" industrial areas as well. Structural change modifies the land requirements of business sectors and thus leads to transformationoften former production spaces turn into office space. In some cases, land is sold or rented out. Often the tenants hope to achieve synergies with customers and visibility. Thus, opening company sites might have a further positive side-effect as it saves protection costs.

\subsection{Connecting Through Functions: Everyday Connectivity}

Easily accessible and lively locations that, in addition to the classic workplace, satisfy everyday needs as well as collaborative, independent work, are becoming increasingly important in the "war for talents." Instead of the friction previously feared due to hard industry, the focus is now on the potential of cooperation in the form of synergies and interactions. These can be temporary (events) or long-term and have an impact on different scales (neighbourhood, district, city, regional, supraregional).

As for everyday connectivity, we observed one vital focus in relation to the provision of everyday goods and places for local recreation within walking distance, which is confirmed by research colleagues (Schmitt et al., 2019, p. 37). Companies offer their employees services that promote work-life balance and women's employment close to home, e.g., medical care by doctors or physiotherapists; leisure facilities such as gyms; parcel acceptance points; local supply facilities; or different open spaces for breaks. We describe three different types of everyday connectivity as follows (Figure 2).

\subsubsection{Open (Social) Infrastructures for the Public}

While the integration of everyday uses and social infrastructures on company sites (Campus-Novartis, Googleplex) has been common since the 1980s, the opening of these uses to the neighbourhood has been observed in recent years. For example, in-house children's facilities, canteens, open spaces (Carlsberg Areal, Copenhagen), or even mobility services are made available to the public. On the one hand it is probably more profitable, but on the other hand companies support municipalities by providing services of general interest and making a contribution to urban development. Therefore, they can assume responsibility in the sense of "corporate social responsibility" or "corporate urban responsibility" (Albers \& Hartenstein, 2017). 


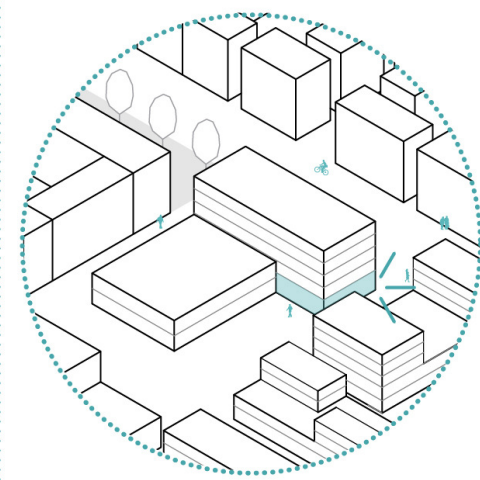

Open: social infrastructure e.g., children's facilities, canteens... are to some extent open to the public

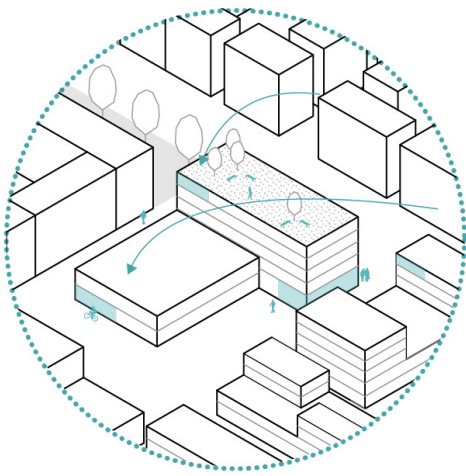

Providing Space: within the company site spaces are rented out to contractors to enrich uses on site

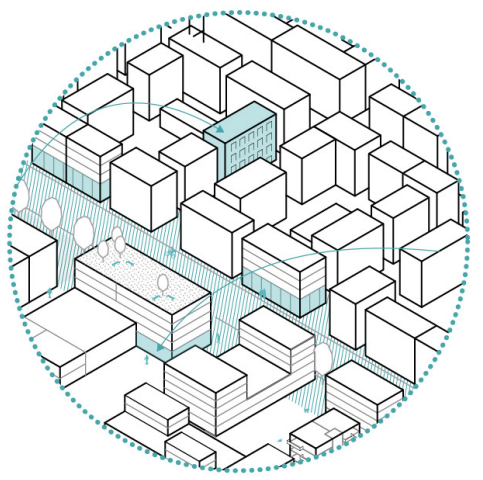

Co-Production: with a critical mass of people/businesses manifold interrelationships are possible

Figure 2. Different types of everyday connectivity (marked in green; see descriptions in Subsections 3.2.1-3.2.3).

\subsubsection{Providing Space for (Social) Infrastructures}

As another way of networking, companies provide space for external operators (coffee shops, therapists, fitness facilities, etc.) that are more-or-less open to the public. In this way, a diverse range of services is offered to the staff and the neighbourhood. Through the joint use of staff and neighbourhood, the necessary critical mass can be reached for some facilities. The uses could include social infrastructure, cultural, and mobility offerings. In smaller urban sites, the shared uses are located at the ground floor level. On larger sites, buildings can be the interface with the surrounding area. In both cases, they serve as intermediaries between company and the city.

\subsubsection{Co-Production of (Social) Infrastructures}

If a critical mass is created by businesses and neighbourhoods, larger developments might take place. These can be a combination of different uses on the factory site and decentralised uses in the neighbourhood. The distribution of uses on both sides (factory site and neighbourhood) may lead to the necessary exchange and interaction with the surroundings. Furthermore, a cooperative development (participation, surveys) of uses can be observed. In this way, the development of the site is much more about looking at the needs of the neighbourhood and including them into the development. An interest in cooperation is shown and can contribute to social networking. The Ikea site (under construction) at the Vienna Westbahnhof provides a good example, as the inclusion of a vertical park and a public roof garden into the design scheme makes up for the missing open spaces in the neighbourhood.

\subsection{Connecting Through Functions: Professional Activities}

The transformation to a science-based society and the growing importance of collaborative cooperation are leading to the dissolution of isolated structures. Spaces for collaborative work and spatial proximity to the scientific and urban society gain importance. Companies open available space due to structural change or corporate restructuring (e.g., relocation of traditional production to Eastern Europe/Global South or centralisation of corporate divisions) and thus shape change. Three developments can be observed: transformation, collaboration, and development-depending on the company location, the size of the vacant plots/spaces, the life cycle of the building structures, or the type of industry (Figure 3 ).

\subsubsection{Transformation of Existing Properties: Rental Spaces Expand Professional Connectivity}

A strong focus of site development is the transformation of existing properties. Areas that have become obsolete due to restructuring (e.g., relocation abroad, reduced demand of office spaces) are sold or rented to new users. The primary focus is on renting to strategic partners who are part of the value chain or to scientific institutions, founders, and start-ups. At strategically or historically important locations, the companies develop the site themselves. For example, Siemens Real Estate develops "technoparks" in the sense of multiple use. Similar to classic business parks, tenants can take advantage of a wide range of space, services, and infrastructure such as area management. Tenants are thus relieved and can concentrate on their core work, cooperation opportunities, and synergies, which also benefit the developing company (Siemens) in addition to raising rent. The communication and networking of companies are mostly in the foreground of the developments. However, depending on the existing environment, connecting through daily activities is also the goal. Another form of transformation, which is primarily motivated by the growth of mobile working (strengthened by Covid-19 pandemic), is the transformation of central locations into mobile work places (e.g., Bosch-Leonberg, Siemens-CoWorking). On the one hand, these are meant for the company's own 


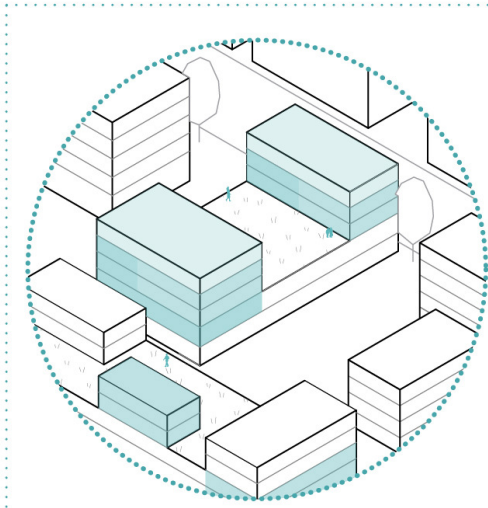

Transformation: well-connected sites are restructured to meet new working requirements

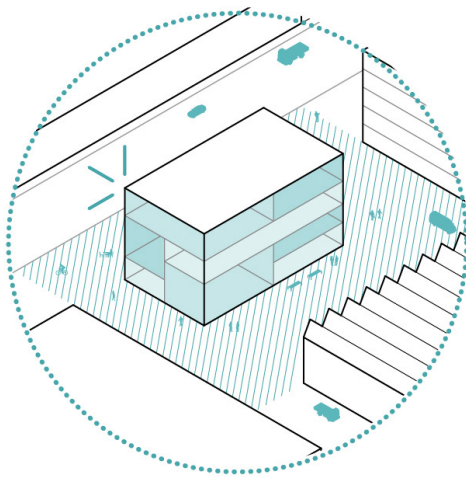

Collaboration: hub buildings are under development (realized jointly from different firms) to meet new needs.

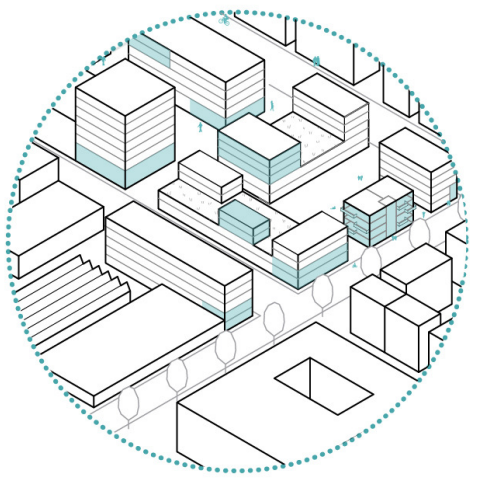

Development: districts that point out the way into the future, $\mathrm{CO}_{2}-$ neutral, variously networked...

Figure 3. Types of connecting professional activities (marked in green; see descriptions in Subsections 3.3.1-3.3.3).

employees, but can also be used by registered users or the general public. Some companies open some areas (often the ground floor spaces) to the public, as the Linkedln co-working space does.

\subsubsection{Collaboration: Companies Develop Locations Together}

The network-like, project-related cooperation is reflected in real estate development. In addition to the content-related mergers on individual topics and the promotion of innovation, the first spatially effective mergers of companies can be observed. Different companies are joining forces as artificial intelligence innovation campuses or hubs. They cooperate in developing locations on a new site or on a company's own site.

\subsubsection{Development of Future Manufacturing Districts}

Another form is a highly investment-intensive transformation that can be observed in traditional locations. For example, Siemens Real Estate in Erlangen is developing an urban district together with scientific institutions and the municipality. A connected district, the Siemens Campus, will gradually emerge until 2030 from a previously isolated factory site to a $\mathrm{CO}_{2}$-neutral district in the sense of innovative, sustainable, and future-oriented urban development. A similar development is going on for Siemensstadt in Berlin, which was built at the end of the 19th century as a company location, including company-owned flats, cultural, and social facilities. This area will change to a mixed, productive, and dense smart city. The cross-linking potential for city and companies to gain synergies are enormous but the city has to keep track of the social interest as well. In addition, such developments can serve as pioneers for further developments, in terms of resource-saving development and the circular economy.

\section{4. "Experience Factory"}

Besides spatial and functional ways of interconnecting for employees or professional contractors as described before, companies are paying attention to soft site factors named below (Figure 4).

For a long time, company premises were only accessible to employees and the first factory tours were mainly for the employees' relatives and neighbours of the site. While at that time the guided tours were intended to dispel the fear of the industry, which was perceived as critical, as a neighbour and to achieve an understanding and experience of production, the guided tours became more professional and were supplemented by exhibition rooms. The invitees were expanded to include customers and people interested in technology, and a separate market was created. Industrial tourism developed in the early 20th century, especially in food production and automotive factories (Rappaport, 2019, p. 440). Over time, production-related functions increased (Sgobba, 2012 , p. 281) and the visibility and emotional participation in the production of an automobile reached its peak in the "Gläserne Manufaktur" ("transparent factory") of Volkswagen in Dresden. Entire worlds of experience were created, especially in the automotive sector, through the enrichment of further functions (museum, park, visitor centre), as is visible, for example, in Wolfsburg (Autostadt Wolfsburg), Munich (BMW Welt), or Herzogenaurach (Adidas World of Sports).

On the one hand, these serve to build image and brand loyalty and, on the other, have an enormous influence on the context. The worlds of experience developed into a tourist magnet, created new markets with the visitors and attracted new uses (hotels, restaurants, etc.) and events. By developing "brand hubs" (comprehensive urban development projects), companies use cities as stages and also make an important contribution to the attractiveness of the city as a business location (Höger, 2007; Hüttenhain, 2012, p. 29). Networking ranges from 


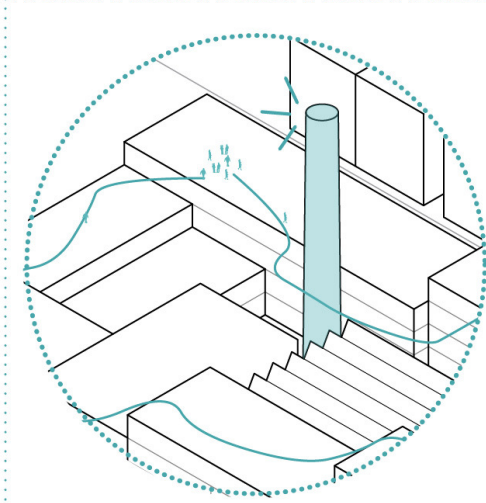

Factory Tours: first step to give insight to the company and reduce prejudices

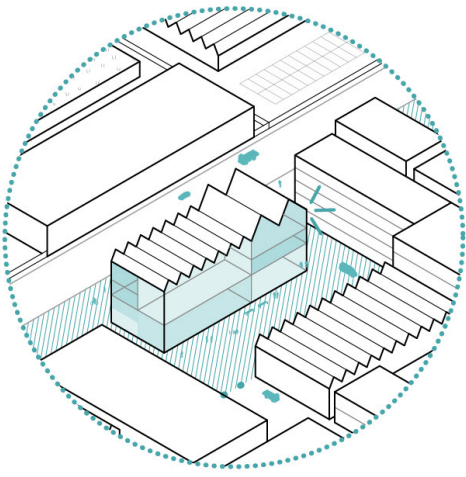

Transparent Factory: Customer loyalty and branding can be supported through visibility

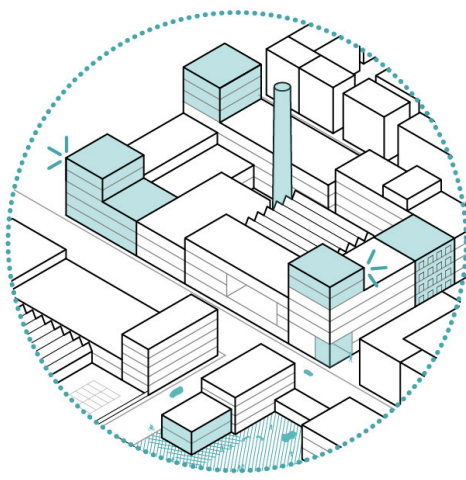

World of Experience: mutual interactions create new markets and support branding/brand loyality

Figure 4. "Experience Factory" (potential to connect is marked in green; see description in Subsection 3.4).

small-scale qualification of public spaces and the creation of new jobs and new markets to buildings that shape the cityscape.

In the context of urban production and the increasing demand for fairly- and environmentally-produced products, it is evident that transparency and mutual interactions can become the focus of future developments. In this way, work and the production of goods can heighten the value of work (Rappaport, 2019, p. 439) and contribute to raising awareness and creating acceptance among the population for production and products. An important aspect in this context is that local residents accept disturbances to a certain extent. The development on urban sites is favoured above all by digitalisation and 3D printing in small series and individual production in the sense of urban manufactories. Transparent factories can take place in the urban context in the sense of urban manufactories and urban production (e.g., Manner) or at non-central locations (e.g., Volkswagen). Hopefully, further imitators will follow suit.

\section{Study Results: Company Sites and Industrial Areas-From NoGo to Go}

The previously described observations about spatial and functional connections between companies and surrounding neighbourhoods show that cooperation takes place in different ways. It is obvious that urban planning and design have different influences on site development. Companies are more interested in connectivity at headquarters or at research and development sites than at simple production or logistic sites.

As pointed out before, industrial areas will play an important role, if cities follow the strategic goals of the Leipzig Charter to develop "just, green and productive cities," and cities probably are the incubator for the renewal of industry (Läpple, 2020, p. 23). Therefore, we generalise some aspects that urban planning and design might assess to support vibrant industrial areas. However, we do not consider simple production and logistics locations or small-scale structured industrial areas in the following subsections. Aspects such as the regional economic situation, the size of the city, the ownership structure, the availability of skilled workers, proximity to knowledge institutions, or the state of renovation of the company's real estate are important for future development of companies but they are not part of the following consideration.

Looking at the urban context (Figure 5), three company site locations can be identified that show potential for connectivity (see Subsection 4.1; Figure 6). These are followed up with some considerations on the importance of strategic urban planning (see Subsection 4.2).

\subsection{Company Sites and Potential for Connectivity}

\subsubsection{Isolated Site: Internal Qualification}

Isolated sites are characterised by a peripheral location without a direct urban context. The locations were mainly developed during the heyday of motorised individual transport and are therefore mostly located on major roads. Accordingly, the public transport connection is subordinate.

The potential of connectivity in these locations is the transformation on-premise. Qualification can take place in the form of improvement of various modes of mobility, representative architecture, (re)densification, enrichment of use, and urban quality. Functional connection through social infrastructures can only be realised if a critical mass of employees is reached. Considerable potential for connectivity is offered by ground-floor uses, e.g., as parcel shops or small service providers, which at the same time favour an upgrading and frequenting of the open space. Further potential lies in networking improvement (of the working world). Restructuring or redensification offers the possibility of providing space to 


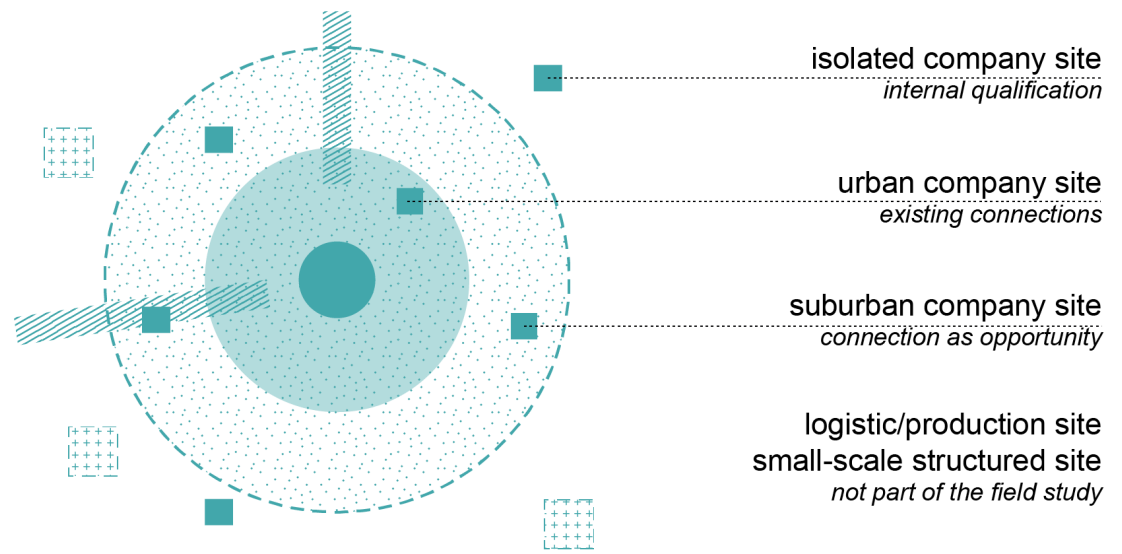

Figure 5. Company sites: From NoGo to Go. Source: Own drawing based on Roost et al. (2021, p. 37).

new tenants to create synergies (partnerships and cooperation with both academia and competing firms, or with companies that add value or offer a perfect complement). The only spatial interfaces with the surroundings are the street and the buildings along the street that could be created as landmarks.

\subsubsection{Urban Site: Existing Connections}

Urban sites are characterised by density and often a mix-use context. A lot of these sites have already been changed (e.g., densified, opened, qualified) some years previously. They benefit from social and cultural infrastructure, good public transport connections, and offer many points for connectivity. Due to a long-standing proximity of company and neighbourhood, a social network with the factory site might already exist and might be extended for alternating interconnections, e.g., temporary use or events can serve to increase visibility and identification. A spatial opening of previously fenced historic factory sites and the right of passage through the site could be another option for connectivity. Some of the areas still have potential for restructuring and vertical redensification to enrich uses, as a study called "Urban Sandwich" by the city of Stuttgart shows (Landeshauptstadt Stuttgart, 2020). Accordingly, missing uses or public spaces in the area can be realised by companies, and connectivity with the neighbourhood can be created. Functional connectivity can take place on a small scale through public ground floor zones or rooftop uses as well as on a large scale through a world of experience or the addition of further building blocks such as museums, hotels, educational institutions, or visitor centres. Challenges in urban sites include high land prices and logistics. However, new concepts for urban logistic can already be explored (Industrie- und Handelskammer Region Stuttgart, 2020).

Looking at urban sites it is obvious that they offer great potential for less land-intensive uses such as urban production, research and development, or innovation clusters.

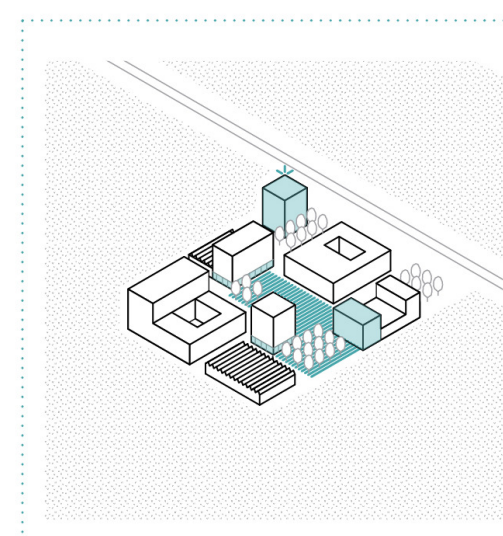

Isolated Site: connectivity through transformation on premise

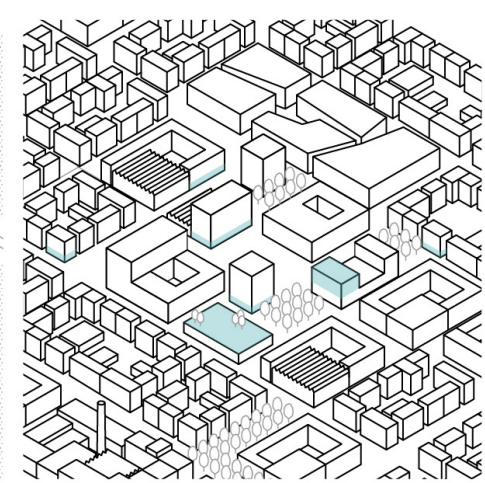

Urban Site: connectivity already exists, potential for expansion

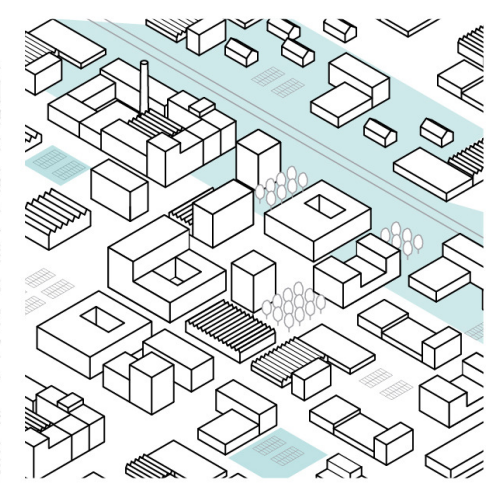

Suburban Site: connectivity through complementary mobility infrastructure and missing uses

Figure 6. Company sites and potential for connectivity (marked in green; see descriptions in Subsections 4.1.1-4.1.3). 


\subsubsection{Suburban Site: Connection as Opportunity}

Another widespread type of site with high potential and necessity for transformation is the "Zwischenstadt" (in-between city). According to Sieverts (1997), characterised by a dispersed and separated development of residential neighbourhoods and industrial areas, in some cases with spacious undeveloped transition zones. Mostly these areas are accessible by car, but often a favourable location would be suitable to improve public transport and therefore lower traffic problems. Due to the lower land prices in the surrounding area, there are single-storey commercial halls, ground-level parking areas, and large undeveloped areas that offer potential for redensification and connectivity. When both sides (company and neighbourhood) create a critical mass, new uses become profitable and both sides benefit. Uses could serve the living environment (fitness studio, e-charging stations) or the working environment (co-working, start-up centres). The improvement of environmentally friendly mobility (mobility hubs, public transport, car and bike sharing) and the reorganisation of ground-level parking areas enable the development of new space potentials. Another option to reach connectivity would be to build on the transition zone areas in such a way that the new buildings complement the existing uses and mediate between the different building blocks in case there are scale jumps. Adequate uses might be education institutions or mix-use areas for local supply. By organising them in commercial courtyards, costs can be lowered, uses and resources can be bundled, and synergies can be created (built examples include Munich, Hamburg). Another option is to share resources in the sense of a zero-emission park. In addition to functional connections, the continuation and spatial qualification of pathways and public spaces can be another option to improve connectivity and location quality.

As described, the suburban site shows great potential of transformation to better integrate industrial areas spatially and functionally through complementary mobility infrastructure or missing uses that might suit the existing working and/or living district. One challenge in this context, however, will be to counteract possible gentrification. The instruments for this are available and wellknown, but they also have to be put into use.

\subsection{Dimensions of Strategic Urban Planning}

Evidently, urban planning and design as set out in the Leipzig Charter need strategic planning in interdisciplinary teams of the municipality, including stakeholders, in order to balance the various interests of global and local businesses and urban society on site in a co-productive design process. Demand-related planning, land-use planning, and sectoral thinking will no longer be sufficient. Instead, it is necessary to precisely know the requirements of the different industrial areas and the dynamic/potential of change and moderate transformation processes, and take an active role to set development impulses (Eckmann et al., 2020, p. 49; Hüttenhain, 2012, pp. 216-223).

Possible scales and ways of strategic urban planning that support connectivity are described below (Figure 7).

\subsubsection{Sharing Spaces and Services}

The study shows that bigger companies are highly interconnected on site. If possible, they have already established greywater use and treatment, use waste heat for other processes, or try to establish material cycles.

In the urban context, sharing of resources (e.g., services, energy, mobility) gains more and more attraction, but there is still a lot of room to improve. Sharing of resources in the form of cooperation, associations, contribution payments, and cooperatives offer the possibility to take care of issues such as reserve areas or the qualification of locations (quality of stay, enrichment with uses, improvement of mobility, etc.). On the other

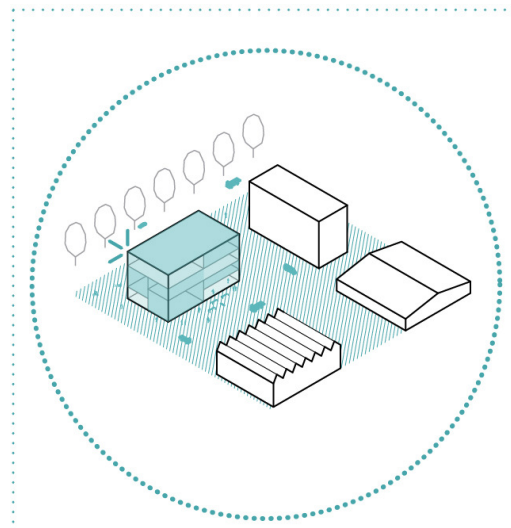

Sharing Spaces and Services: small and local companies can be supported if sharing is promoted

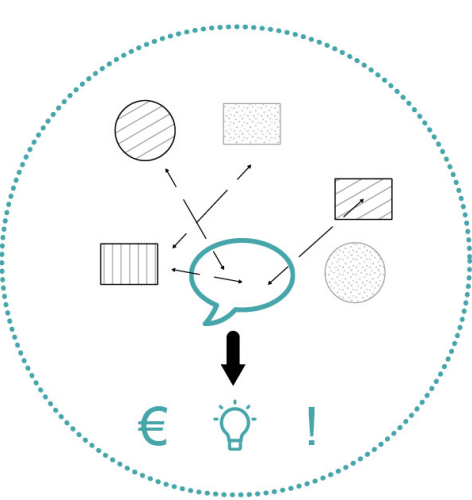

Managing Industrial Areas: combining know-how in industrial area increases competitiveness

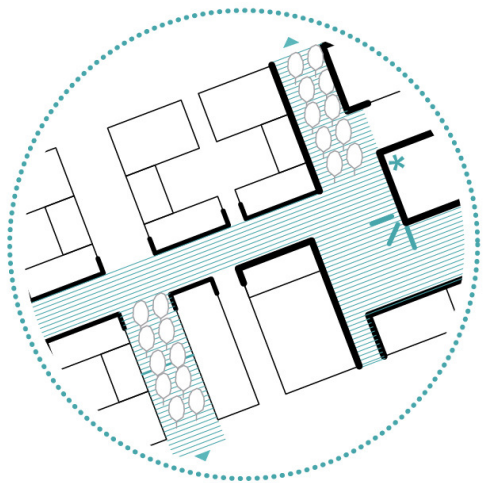

Act Strategically: the necessary transformation of industrial areas can be supported by strategic planning

Figure 7. Scales of strategic urban planning (marked in green; see descriptions in Subsections 4.2.1-4.2.3). 
hand, building associations such as commercial courtyards offer new opportunities for companies. For example, certain areas can be shared, expansion areas can be rented jointly or, in the case of municipal commercial courtyards, areas can be rented or given on a leasehold basis, thus ensuring the municipality's long-term ability to act. Similar to the social land use, financially weaker companies or unprofitable uses can still be enabled to use certain locations in this way.

\subsubsection{Managing Industrial Areas}

Headquarters of global companies often combine production, offices, and retail on the same site. The internal planning department choreographs the spatial development and transformation of the existing site. Castling of plots and spaces, redensifying, or unsealing depend on the respective needs.

In existing industrial areas within the city, it is often difficult to know the requirements and perspectives of all the local companies and sometimes they differ. Furthermore, individual companies lack the resources (financial, spatial) or ideas to transform an area. However, usually individual companies would welcome the enhancement of the industrial area to be attractive for employees and associates.

To accompany transformation processes, local companies can therefore come together to form an association, cooperative, or location initiative to implement individual measures (greening, parking solutions, etc.) or to develop a marketing or a transformation strategy together with the municipality.

In addition to the association of individual companies, "business park" management can also be implemented by the municipality itself, or by an external office to ensure future viability of existing industrial areas, or to remain true to the principle of inner development before outer development. Studies show that it is useful to have a curator (team) to mediate between different local firms, administration departments, or to initiate network events (see, e.g., Bundesinstitut für Bau-, Stadtund Raumforschung, 2020, pp. 40-45).

\subsubsection{Act Strategically!}

Companies with real estate departments in general act strategically and this enables them to successively transform existing industrial sites into attractive urban sites with qualities that employees appreciate and with spaces designed in a way that takes into account, for example, accessibility or noise and challenges are spatially resolved. But companies pay attention mainly to priority sites.

In existing industrial areas most of the individual firms (including the global players) are not yet thinking about the district and ways of transforming. Usually, smaller firms lack resources and/or know-how and therefore it turns out that municipalities have to initiate strate- gic planning and collect data about the firms and their development goals or vacancies. In this context, it is necessary to work in interdisciplinary teams of different city departments to come up with goals and interventions that support future development and ensure competitiveness. It will be advantageous if strategic planning views industrial areas as laboratories of urban development and therefore experiments with new forms of sustainable and energy-efficient construction, climate adaptation strategies, new forms of mobility, and new financing models. Depending on the site location and economic pressures it should be examined whether urban development funding could be applied to industrial areas. This might help counteract upgrading processes and save non-profitable uses that are important for social coherence, as Dieter Läpple emphasises, perpetually (see, e.g., Läpple, 2020, p. 17). The Wuppertal Institute argues, similarly, that two recent studies point out the necessity to act with more resilience (Schneidewind et al., 2020; Wuppertal Institut, 2020). Positive approaches to co-productive urban development can be experienced first-hand (completed projects such as Werksviertel Munich or Basel-Dreispitz, and conceptual phases, such as IBA'27, Stuttgart Region).

\section{Conclusions}

Multi-national companies have a decisive influence on urban development and some of them show innovative ways of connecting industrial areas with neighbourhoods that can be an inspiration for urban planning representatives (see Section 3). But reasons for and strategies of connectivity are complex, as spatial ideas and the impact of transformation processes vary. Therefore, multi-national companies force connectivity with great effort-possibly through concentration and consolidation of business sectors - on headquarter and/or priority locations (especially for urban sites (see Subsection 4.1.2) and isolated sites (see Subsection 4.1.1), while other locations are abandoned for various reasons.

As industrial areas add up to about 20 percent of the settlement area, they obviously have great relevance for future urban development. The hidden reserve of industrial areas-not only for company sites, but in general terms-needs more attention if urban planning wants to make its contribution to "just, green and productive cities," as pointed out in the Leipzig Charter (EU, 2020). Obviously, municipality and the planning department have a special responsibility to give spatial expression to the transformative power of cities and this includes industrial sites. In particular, the widespread suburban sites (see Subsection 4.1.3), small-scale structured industrial areas, or peripheral logistics locations play an important role in developing productive cities. But only some planners and cities are aware of this, at the time of writing.

One step to achieve this goal would be to overcome thinking in terms of separation of functions 
(black and white/ego-perspective). Instead, it is vital to think more about interdependencies and interconnecting spaces (shades of grey/common perspective), even if this requires greater effort and creating awareness of mutual dependencies. The full impact of the Covid-19 pandemic is unknown yet, but several scientists (e.g., Horx, 2020; Läpple, 2020; Schneidewind et al., 2020) see greater willingness and the necessity of what one might call the approach of "as well as" or of concomitant interventions. In the context of industrial sites, this means to think "global and local" or "urban and suburban" or "city-friendly and dirty/noisy industrial areas" to name just a few pairs of opposites that need to be suitably recombined or zoned rather than separated. This does not mean that all industrial areas should be transformed to meet different requirements. Rather, a precise analysis of local pressures and circumstances may help reach more productivity and mix-uses and therefore develop new building types for denser industrial areas. See, for example, the study "Urban Sandwich" (Landeshauptstadt Stuttgart, 2020) or developing industrial courtyards (Reiß-Schmidt, 2010, pp. 49-51). In other areas it may be, on the contrary, necessary to prevent undesirable side effects of upgrading (e.g., displacement). As the instruments of urban development funding are already well known, it should be examined how to create awareness for these themes and apply them to industrial areas.

It will be advantageous to focus on strategic urban planning that balances the various interests of local and global businesses and urban society in a co-productive design process. As described above, demand-related planning, land use planning, sectoral thinking, or finished pictures of future development will no longer be sufficient for urban planning processes in existing industrial areas. In this regard, multi-national companies make a strong case. Instead, it is necessary to moderate transformation processes and in some cases take an active role to set development impulses. The basis for this will be to precisely document existing site qualities, know the requirements of local companies, and develop a locally coordinated understanding for a desirable common urban future. In this context, industrial areas must be seen as laboratories of urban development, trying new forms of sustainable and energy-efficient processes or working in interdisciplinary cooperation. At the same time, it is necessary to have a climate that promotes innovation, focussing not only on technical or functional aspects (new mobility concepts, broadband expansion, and other infrastructure) but also struggling for the appropriate space and atmosphere. Depending on the site and its priority, transformation processes could be comprehensive, reaching vitally connected areas or it could simply mean to re-zone street spaces and add some green spaces to reduce overheating. Every step towards "more city" in industrial areas is an earning to a "just, green and productive" future of our cities. This requires more courage for, and joy in experimenting for all stakeholders.

\section{Acknowledgments}

We thank the interview partners Albrecht Fischer (Bosch, formerly), Thomas Glatte (BASF), Herbert Grebenc (BMW, formerly), Mathias Lutz (Wirtschaftsförderung Verband Region Stuttgart), Jürgen Schäfer (Trumpf), Zsolt Sluitner (Siemens), Markus Weismann (asp Architekten Stuttgart), for the time and effort they spent on conversations about our ideas on connecting company sites with the city.

\section{Conflict of Interests}

The authors declare no conflict of interests.

\section{References}

Albers, H.-H., \& Hartenstein, F. (Eds.). (2017). CSR und Stadtentwicklung. Unternehmen als Partner für eine nachhaltige Stadtentwicklung [CSR and urban development. Businesses as partners for sustainable urban development]. Springer. https://doi.org/ 10.1007/978-3-662-50313-3

Bathen, A., Bunse, J., Gärtner, S., Meyer, K., Lindner, A., Schambelon, S., Schonlau, M., \& Westhoff, S. (2019). Handbuch Urbane Produktion. Potenziale, Wege, Maßnahmen [Handbook urban production. Potentials, pathways, recommendations]. UrbaneProduktion.Ruhr. https://urbaneproduktion.ruhr/ wp-content/uploads/2019/12/Handbuch-UrbaneProduktion_2019_Web.pdf

Böhme, H. (2004). Stadt und Arbeit-Integration und Ausgrenzung. Überlegungen aus historischer Sicht [City and work-integration and separation. Historical considerations]. In I. Flagge \& F. Pesch (Eds.), Stadt und Wirtschaft [City and economy] (pp. 180-192). Das Beispiel.

Bundesinstitut für Bau-, Stadt- und Raumforschung. (Ed.). (2020). Nachhaltige Weiterentwicklung von Gewerbegebieten [Sustainable development of working areas]. Bundesamt für Bauwesen und Raumordnung. https://nbn-resolving.org/urn:nbn:de:101:12020060310275862721226

Croxford, B., Domenech, T., Hausleitner, B., Hill, A. V., Meyer, H., Orban, A., Muñoz Sanz, V., Vanin, F., \& Warden, J. (2020). Foundries of the future: A guide for 21st century cities of making. TU Delft Open. https://books.bk.tudelft.nl/press/catalog/book/ ISBN_9789463662475

Daldrop, N. (2004). Corporate Identity und Architekturmehr als nur Fassade [Corporate identity and architecture-More than facade]. In N. Daldrop (Ed.), Kompendium Corporate Identity und Corporate Design [Compendium corporate identity and corporate design] (pp. 58-65). av-edition.

Eckmann, B., Holthey, L., Krüger, T., \& Spars, G. (2020). Perspektiven für Gewerbe und Produktion in der Stadt [Perspectives for industry and manufacturing in 
the city]. RaumPlanung, 209(06), 44-49.

EU. (2020). The New Leipzig Charter. The transformative power of cities for the common good. https://eurocities.eu/wp-content/uploads/2020/ 12/New-leipzig-charter_2020.pdf

Förster, A., Wenzel, S., \& Thierstein, A. (2017). Gewerbe \& Stadt. Gemeinsam Zukunft gestalten [Working \& city. Co-designing future]. Studio Stadt Region and Technische Universität München. https://mediatum. ub.tum.de/doc/1398132/1398132.pdf

Häussermann, H., Läpple, D., \& Siebel, W. (2008). Stadtpolitik [Urban policy]. Suhrkamp.

Höger, K. (2007). Brandhubs: Markenzeichen im Stadtraum [Brandhubs: Brands in urban spaces]. Informationen zur Raumentwicklung (IzR), 2007(12), 705-718. http://www.kerstinhoeger.com/HOEGER/ publications/0712_Brandhubs_IrZ-Bonn.pdf

Horx, M. (2020). Die Städte von morgen-6 Thesen für die urbane Post-Corona-Welt [The cities of tomorrow-6 theses for the urban post-corona world]. Informationen zur Raumentwicklung (IzR), 2020(4), 118-125.

Hosoya, H., \& Schäfer, M. (2020). Industrie.Stadt. Urbane Industrie im digitalen Zeitalter [The industrious city: Urban industry in the digital age]. Lars Müller Verlag. Hüttenhain, B. (2012). Stadtentwicklung und Wirtschaft: Strategien und Handlungsansätze zur Entwicklung von Gewerbestandorten [Strategies and instruction for the development of business locations]. Dorothea Rohn.

Industrie und Handelskammer Region Stuttgart. (Ed.). (2020). City-Logistik neu gedacht. Impulse für das Stuttgarter Rosensteinviertel [City logistics rethought. Impulse for Stuttgart's Rosenstein district]. https:// www.stuttgart.ink24.de/blueprint/servlet/resource/ blob/4877820/0df009e26df44c518419c023bc65 a68d/rosensteinstudie-pdf-final-data.pdf

Landeshauptstadt Stuttgart. (Ed.). (2020). Urban Sandwich-Steigerung der Flächeneffizienz durch Stapelung gewerblicher Nutzungen [Urban Sandwich-Increasing space efficiency by stacking commercial uses]. https://www.stuttgart.de/medien/ ibs/Abschlussbericht_Urban_Sandwich_2020.pdf

Läpple, D. (2019). Neue Arbeitswelten-eine Einführung [New working worlds-An introduction]. Informationen zur Raumentwicklung (IzR), 2019(6), 4-19.

Läpple, D. (2020). On the significance of the productive city in the pandemic era. Lessons from the Corona pandemic. In Europan Deutschland (Ed.), Europan 15, Produktive Städte 2 [Europan 15, Productive cities 2] (pp. 15-25). Jovis.

Möllers, C., Schmitt, G., \& Klanten, C. (2020). Produktion in die Stadtstruktur einfügen [Integrate production into the urban structure]. RaumPlanung, 209(06), 21-27.

Pesch, F. (2004). Urbanität und Wirtschaft-Die Stadt und das Städtische im Spiegel der wirtschaftlichen Entwicklung [Urbanity and economy-City and the urban in the mirror of the economic development]. In
I. Flagge \& F. Pesch (Eds.), Stadt und Wirtschaft [City and economy] (pp. 8-26). Das Beispiel.

Rappaport, N. (2019). Vertical urban factory (2nd ed.). Actar Publishers.

Reiß-Schmidt, S. (2010). Gewerbe und Handwerk in der Stadt-Beispiel München [Trade and crafts in the city-The example of Munich]. In Deutscher Industrie-und Handelskammertag (Ed.), Experimentierfeld Stadt. Handel, Handwerk und Gewerbe im 21. Jahrhundert [Experimenting in the city. Trade, crafts and commerce in the 21st century] (pp. 49-51). DIHK Berlin.

Roost, F., Baur, C., Bentlin, F., Höfler, J., Hüttenhain, B., Jeckel, E., Kübler, A., Millon, A., \& Werrer, S. (2021). Vom Gewerbegebiet zum produktiven Stadtquartier: Dienstleistungs-und Industriestandorte als Labore und Impulsgeber für nachhaltige Stadtentwicklung [Turning business parks to productive urban quarters: Commercial and industrial areas as laboratories and impulses for sustainable urban development]. Bundesinstitut für Bau-, Stadt- und Raumforschung.

Schmitt, G., Klanten, C., \& Shapiro, J. (2019). Produktion stadtverträglich integrieren. Ein Forschungsbericht im Rahmen des Verbundprojektes MIA-Made in Aachen [Integrating production compatible with the city. A research report within the framework of the joint project MIA-Made in Aachen]. RWTH Aachen University. https://doi.org/10.18154/RWTH2020-02261

Schneidewind, U., Baedeker, C., Bierwirth, A., Caplan, A., \& Haake, H. (2020). Näher, öffentlicher, agiler: Bausteine einer resilienten Post-Corona-Stadt [Closer, more public, more agile: How to build a resilient post-Corona city]. GAIA, 29(2), 134-136. https://doi.org/10.14512/gaia.29.2.15

Sgobba, A. (2012). Architektur, Stadt und Automobilindustrie: Entwicklungstendenzen und Paradigmenwechsel im Informationszeitalter [City and automotive industry: Development trends and paradigm shifts in the information age]. Dorothea Rohn.

Sieverts, T. (1997). Zwischenstadt: Zwischen Ort und Welt, Raum und Zeit, Stadt und Land [In-between city: Between place and world, space and time, city and countryside]. Vieweg.

Stadtentwicklung Wien. (Ed.). (2017). STEP 2025Fachkonzept Produktive Stadt [STEP 2025-Strategic urban planning productive city]. https://www.wien. gv.at/stadtentwicklung/studien/pdf/b008500a.pdf

Vonseelen, T. (2012). Von Erdbeeren und Wolkenkratzern: Corporate Architecture-Begründung, Geschichte und Ausprägung einer architektonischen Imagestrategie [Of strawberries and skyscrapers: Corporate architecture-Justification, history and development of an architectural image strategy]. Athena.

Wuppertal Institut. (2020). Wirtschaftsförderung 4.0. Rahmenarbeitsbericht [Economic development 4.0. Framework work report]. 


\section{About the Authors}

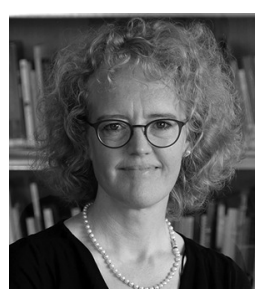

Britta Hüttenhain (PhD) is academic director at the University of Stuttgart, Institute of Urban Planning and Design in the Faculty of Architecture and Urban Planning and Design, Stuttgart, Germany. In research and teaching she reflects on urban history, urban typology, and urban development planning. She focuses on strategies and approaches for the spatial development of cities, redensification, and sustainability with special interest in industrial/commercial/knowledge/inner-city districts.

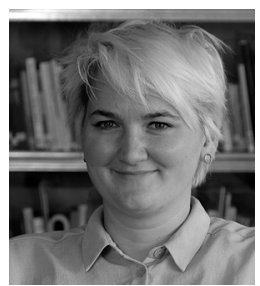

Anna Ilonka Kübler is a German architect and urban planner. As in her master's thesis (2015), she explores the issues and role of shared uses in urban planning and urban typologies in different offices in Switzerland and Germany. She was research and teaching assistant (2019-2020) at the University of Stuttgart, Institute of Urban Planning and Design in the Faculty of Architecture and Urban Planning and Design, Stuttgart, Germany, and part of the research project "GEPRO-Turning Business Parks to Productive Urban Quarters." 